\title{
Are Educational Games Engaging and Motivating Moroccan Students to Learn Physics? An Experimental Study
}

\author{
https://doi.org/10.3991/ijet.v14i16.10641 \\ Jalal Khouna ${ }^{\bowtie}$, Lotfi Ajana, Ahmed Rhazal, Abdelilah El Mokri \\ Sidi Mohammed Ben Abdellah University, Fez, Morocco \\ jalal.khouna@usmba.ac.ma
}

\begin{abstract}
Nowadays and since the year 2000, the Moroccan educational system like all the other system of educations evolve towards putting more and more emphasis on the Competency-based approach rather than learning contents. Specific pedagogical tool is necessary to develop such competences, especially with the well-known rupture between teaching practices and the digital culture of young people, marked by the increased use of information and communication technologies. Pedagogies that rely on the use of educational games emerged as a solution to change traditional practices .In this sense, we have experimented with the use of educational game circuit warz in a physics classroom .We have restricted its use to the lesson of the voltage divider and we have compared its contributions to those of a classical teaching method . The results found a huge improvement in areas like motivation, engagement and interaction inter-learners.
\end{abstract}

Keywords - Educational game, motivation, engagement, interaction, learners, physics, Competency-based approach

\section{$1 \quad$ Introduction}

Along the past years, there has been an increasing interest in the educational games that used in many different fields such as health training, military training [1] and teaching of several subjects, such as physics [2]. Several factors have led towards this interest in teaching through educational games, namely the availability of technological tools to create learning game and the need to change traditional learning methods for more innovative method [3].Educational video-game based learning focuses on two elements ; the cognitive element and the emotional element .In regard to the emotional side, several studies claim that playing games greatly increases the motivation of learners; this assertion is often supported by the fact that games generate intrinsic motivation such as challenge, curiosity, competition and cooperation. In regards to the cognitive side, educational games can be used as interactive simulations that facilitate learning. Moreover, this type of game helps the learner develop competences and 
knowledge by generating a deeper understanding of certain concepts and principles by immersing the player in the game [1].

Understanding the concepts and notions of physics is difficult for most learners which is why they lose interest in this subject. And since it is involved in almost all fields engineering, electronics, medicine, it is essential that the basic concepts can be understood by the majority of learners. Today, thanks to the increased development of technological means and particularly to the use of educational games, we have a new method of teaching that has provided a solution to the encountered problems. [4]

In this context, we have experimented class with the educational video game circuit warz. The choice of this game is based on the results of a selection gird that we have developed according to the Moroccan context. The objective of this experiment is to study the impact of this video game on the motivation and engagement of the learners as well as the interaction inter-learners and between the learner and the teacher. The studies that have already been carried out to find out upon the attitude of learners towards the use of this educational tool are motivating. It proves that the majority of Moroccan learners have a positive attitude concerning the integration of educational games in class, as well as proving that the activity of playing occupies an important place in their universe [5].

During our research of a video game, we encountered great difficulty to make a choice and the reason was the absence of games on science physics whose learning content was integrated into the Moroccan curriculum, compatible with Competencybased approach and that meets the expectation of the Moroccan learner. In fact the most part of the games we were able to find were simple simulations..

\section{Problematic}

The question of the integration of educational games in class remains a theme of interest for many researchers and teachers. The impact of motivation and engagement is felt by this new generation of learners, who grew up with computers, video games and the internet in this new digital era [3] .most Moroccan learners spend a lot of time playing video games[5] and as a result, they have developed the skills needed to solve problem situations. Therefore, the traditional course approach based on traditional methods no longer enjoys of the support of learners that find themselves in passive state when they have many digital resources at their disposal [3]. In addition, a synthesis of recent publications that address the impact of playing games shows that this activity has a positive impact on the learning motivation [6],[7].

Based on previous and a research that had already been made on the integration of educational games which revealed that the majority of Moroccan learners have a positive attitude on this point [5]. We proceeded to the experimentation of the educational video game circuit warz in class. The question we keep asking ourselves is this: will the use of the video game circuit warz bring a higher level of motivation, engagement and interaction in class for the Moroccan learner? Hence, the purpose of this work is to make a comparison between the teaching method with educational games and the traditional teaching method. 


\section{Elaboration of The Selection Grid}

Seeing the obvious need to have a tool that allows teachers of physics to select relevant educational games and considering the dissatisfaction presented by the existing tools in their hands, We wanted to produce a simple and practical grid while being the most objective possible to encourage Moroccan teachers to embark on the game experience in the classroom. The determination of the criteria of the grid depends on the following three axes:

- The Moroccan context marked by the adoption of the competency-based approach

- Existing models of grids for analyzing and assessing educational games

- A literature review that focuses on the relevance of educational games

In fact, the majority of educators show an interest in the use of video games for educational purposes, with the main goal of stimulating motivation and school engagement [8].

\subsection{Motivation and competence}

The concepts of motivation and competence are a major concern for teachers interested in learning through video games. The concept of motivation is one of the premises of this movement, due to the strong relationship it maintains with learning [9].As regard to the notion of competence, researchers generally agree on the fact that it relies on the individual's own resources (knowledge, skills and attitudes) and on his ability to mobilize them in singular situations [10].

In the same vein, learner motivation is an important driving factor for skill development [11], [12], [13]. In fact, without interest, it is difficult to integrate new notions, to make links with previous knowledge and to persevere in the appropriation of new concepts. The educators want to find innovative strategies to motivate learners. In this sense the educational games can contribute by its dynamism and playfulness [14].

The use of games seems more particularly conducive to learning when it induces the state of flow to the user. The flow is a state of mind that is generated by an attractive activity which is manifested on the player by concentrating and increasing enjoyment[15], [16], [17], [18]. The engaging and immersive character of a welldesigned video game would have an advantage to be operated for educational purposes, and, particularly with disengaged learners [17].

\subsection{Consistency with the competency-based approach}

Another criterion on which we have insisted a lot in the Moroccan context: it is the coherence of using educational games with the practice of the competency basedapproach which will contribute to the harmonious integration of this digital tools in class .In fact the game must allow to develop skills and / or to deepen school knowledge while respecting the approach of learning, 
In this sense, Oblinger points out that video games represent powerful learning environments because they can support the pedagogical approach based on the resolution of problem situations, in a multisensory, active and experiential way. They also promote the emergence of previous knowledge necessary for advancement in the game and provide immediate feedback, allowing users to test hypotheses and learn from their actions [17].

\subsection{The contents of the games}

Despite the anticipated benefits that educational video games can provide, the link between its learning 'content and the knowledge prescribed in the curriculum is not always assured. The teacher is forced to worry about the integration of the relevant prescribed concepts; otherwise this educational approach might seem slight and insubstantial. However, it seems essential to demonstrate the adequacy between the elements of games used in teaching and those of school programs due to ensure the legitimacy of the educational approach.

On the basis of available models of grids proposed by several researchers [19], [20], [21], [22], [23], [24] and by improving them according to the Moroccan context and the researches regarding the value of using educational games. We developed a selection grid; the grid itself contains four sub-grids corresponding to the four categories mentioned above.

- Viability of the game

- Motivation to play

- The content of the game

- The requirements of the competency-based approach

The method of judgment that we have adopted is very selective, the decision is to put a judgment on each category based on the results obtained:

- For the viability of the game: If the game gets a score of $4 / 7$ or more, it is declared as viable.

- For motivation to play: If the game gets a score of $10 / 20$ or more, it is considered a motivating game.

- For game content: If the game gets a score $12 / 24$ or more, it is consistent with the content.

- For the requirements of the competency-based approach: If the game scores $12 / 24$ or more, it is considered compatible with the requirements of the competency-based approach.

Based on the results obtained for the previous four categories we can reject or adopt the use of the game in Moroccan context, in fact, if one of the categories is not verified the game must be rejected.

Educational games having passed the selection are affected an overall rating determined by weighting 
In relation to our research, we have given more importance to the following two categories 'motivation to play' and 'requirements of the competency-based approach': Indeed, motivation and engagement of the learner is an important criterion during the use of the educational game also, the use of these tools is a part of the competency based-approach 'operationalization. The content of the game is also important but with a less degree compared to the two previous categories

The table 1 represents the weighting factor for each category:

Table 1. The weighting factor

\begin{tabular}{|l|c|}
\hline \multicolumn{1}{|c|}{ Categories } & Weighting Factor \\
\hline Viability of the game & 0,1 \\
\hline Motivation to play & 0.35 \\
\hline Content of the game & 0,2 \\
\hline Requirements of the competency-based approach & 0,35 \\
\hline
\end{tabular}

\subsection{Presentation of the grid}

General description of the educational game

Name of the game:

Main theme announced:

Creator:

Year of creation:_ $\left.\left.\left.\right|_{-}\right|_{-}\right|_{-}$

Material resources:

Computer - Smartphone - Website - Game Console

Language of the game: 


\begin{tabular}{|c|c|}
\hline \multicolumn{2}{|l|}{$\begin{array}{l}\text { viability of the game } \\
\text { For "No" noted } 0 \text { and for "Yes" noted } 1 \text { in case of indecision put } 0\end{array}$} \\
\hline & Yes \\
\hline \multicolumn{2}{|l|}{ Educational aspect: Does the game claim an educational aspect? } \\
\hline \multicolumn{2}{|l|}{$\begin{array}{l}\text { Understanding the Game Controls: The game provides enough basic commands to learn playing } \\
\text { fast }\end{array}$} \\
\hline \multicolumn{2}{|l|}{$\begin{array}{l}\text { The feedback and the evolution in the game: The feedbacks allowing the player to measure his } \\
\text { evolution are clear in the game. }\end{array}$} \\
\hline \multicolumn{2}{|l|}{$\begin{array}{l}\text { The clarity of game' objectives: Does the player understand easily and clearly the objectives and } \\
\text { the purpose of the game? }\end{array}$} \\
\hline \multicolumn{2}{|l|}{ Dynamism of the game: Activities in the play space are varied. } \\
\hline \multicolumn{2}{|l|}{ Gameplay: the gameplay is easy to understand } \\
\hline \multirow{2}{*}{\multicolumn{2}{|c|}{$\begin{array}{r}\text { Help system: The game offers help systems (a manual, and tutorials...) } \\
\text { Motivation to Play ( rate from } 1 \text { to 4) }\end{array}$}} \\
\hline & \\
\hline $\begin{array}{c}\text { 1: Not at. all 2: Very little } 3: \text { A little } 4: A \text { lot } \\
\text { in case of indecision put } 1\end{array}$ & $\begin{array}{l}\text { Rating } \\
\text { (score/4) }\end{array}$ \\
\hline Type of game: the type of game is motivating to the player & $\ldots / 4$ \\
\hline Gameplay: Gameplay is pleasant enough. & $\ldots / 4$ \\
\hline $\begin{array}{l}\text { Progress in the game: The game offers a good evolution of the difficulty curve and motivating } \\
\text { challenges to the player. }\end{array}$ & $\ldots / 4$ \\
\hline $\begin{array}{l}\text { Gaming environment: the gaming environment is sophisticated (the story, graphics and sound } \\
\text { elements). }\end{array}$ & $\ldots / 4$ \\
\hline $\begin{array}{l}\text { Gaming immersion: the game allows player to fully immerse themselves and live the theme with } \\
\text { intensity. }\end{array}$ & $\ldots / 4$ \\
\hline \multicolumn{2}{|l|}{ Game Content ( rate from 1 to 4) } \\
\hline $\begin{array}{c}\text { 1: Not at. all 2: Very little } 3: \text { A little } 4: \text { A lot } \\
\text { in case of indecision put } 1\end{array}$ & $\begin{array}{l}\text { Rating } \\
\text { (score/4) }\end{array}$ \\
\hline The scientific aspect of content: The game has content on scientific topics & \multirow{2}{*}{$\ldots / 4$} \\
\hline $\begin{array}{l}\text { Fidelity of scientific content: the game reproduces with fidelity the essential elements of the } \\
\text { scientific topics }\end{array}$ & \\
\hline $\begin{array}{l}\text { The richness of the content: The nature of the game's scientific content is varied (definitions, } \\
\text { concepts, laws and experiences) }\end{array}$ & $\ldots / 4$ \\
\hline $\begin{array}{l}\text { Consistency of the game with the content of the Curriculum: Correlation of game 'objectives with } \\
\text { scholastic program. }\end{array}$ & $\ldots / 4$ \\
\hline $\begin{array}{l}\text { Identification of learning in game' content: Does the content 'game allows rapid identification of } \\
\text { learning concepts? }\end{array}$ & $\ldots / 4$ \\
\hline $\begin{array}{l}\text { Learning dimensions in the game 'content: The objectives of the game are expressed in terms of } \\
\text { several dimensions (knowledge, know-how, know-how). }\end{array}$ & $\ldots / 4$ \\
\hline \multicolumn{2}{|l|}{ the requirements of the competency-based approach ( rate from 1 to 4 ) } \\
\hline $\begin{array}{c}\text { 1: Not at. all 2: Very little } 3: \text { A little } 4: A \text { lot } \\
\text { in case of indecision put } 1\end{array}$ & $\begin{array}{l}\text { Rating } \\
\text { (score/4) }\end{array}$ \\
\hline $\begin{array}{l}\text { The pedagogical approach: The pedagogical approach on which the game is based having as the } \\
\text { foundation of knowledge building }\end{array}$ & $\ldots / 4$ \\
\hline $\begin{array}{l}\text { Reflection: The nature of the game involves a reflection on the effect produced by each action } \\
\text { from the player. }\end{array}$ & $\ldots / 4$ \\
\hline $\begin{array}{l}\text { Rhythm and personalization of learning: the game allows player to customize the settings of } \\
\text { difficulty and game speed. }\end{array}$ & $\ldots . / 4$ \\
\hline Memorization: The game relies on the retention of player's information. & $\ldots . / 4$ \\
\hline $\begin{array}{l}\text { The mobilization of knowledge: The game presents problem-solving through which each player } \\
\text { uses his knowledge to solve the problem. }\end{array}$ & $\ldots . / 4$ \\
\hline Interaction: The nature of game involves exchanges and discussions between players. & $\ldots . / 4$ \\
\hline
\end{tabular}

Fig. 1. . Grid of selection

\subsection{Application of the Gird}

In what follows we try to apply the proposed grid on an example of educational games used to help teachers to select appropriate game.

We started with an Identification of the educational games that can be used for learning physics before we proceed to an assessment in order to get an idea about the ability to be integrated into the Moroccan context: 
After applying the proposed grid on the educational games by assigning a score for each criterion. Regarding the result of each game we selected the educational game "circuit warz". The results that we obtained for this Game are illustrated above:

- The viability of the game: sum of scores $6 / 7$ in percentage $85,7 \%$.

- Motivation to play: sum of scores $18 / 20$ in percentage $90 \%$.

- Game content: sum of scores 20/24 in percentage 83, 3\%.

- The requirements of the competency-based approach sum of scores:21/2 in percentage $87,5 \%$.

Overall weighted score of the game circuit warz: $87,3 \%$

\subsection{Description of Circuit warz}

Circuit Warz is an educational video game made in the University of Ulster in Ireland in summer 2012. It includes seven complete levels to assess Learners' knowledge of basic electronic circuits including Series Parallel Resistor circuits, Resistor Capacitor (RC) filters, Graetz Bridges, Wheatstone bridges, weighted summing amplifiers, Transistor switches and Oscillator circuits.

The objective of the game: The planet Earth is under threat from an alien invader, their ship is approaching fast. The laser protection system has been sabotaged. In a few minutes the player must repair the generator and save the world.

The game is designed to ensure a high level of user engagement and replayability with a competitive leaderboard element and analytics to measure learner retention. To complete the game successfully the learners needs to have a clear understanding of both the underlying circuit theory and its application. The figure 2 shows the level type, player objective on each level, the related theory and the learning outcomes for each level.

\begin{tabular}{|c|c|c|c|}
\hline Level/Circuit & Objective & Theory & Learning outcomes \\
\hline $\begin{array}{c}\text { Level } 1 \\
\text { Series/parallel }\end{array}$ & $\begin{array}{l}\text { Solve for } \mathrm{R} 1 \text { given } \mathrm{Vi}, \mathrm{R} 2, \mathrm{R} 3 \text { to get } \\
\text { required value } \mathrm{Vo}_{0}\end{array}$ & $V_{o}=\frac{R_{e q} \times V_{i n}}{R_{e q}+R_{1}}$ & $\begin{array}{l}\text { Parallel and series circuits. Equivalent } \\
\text { resistance. Circuits and current flow. }\end{array}$ \\
\hline $\begin{array}{l}\text { Level } 2 \\
\text { RC filter }\end{array}$ & $\begin{array}{l}\text { Solve for R1, C to get target cut off } \\
f_{c}\end{array}$ & $f_{c}=\frac{1}{2 \pi R C}$ & $\begin{array}{l}\text { RC circuits and cut off frequencies } \\
\text { Low/high pass filters. }\end{array}$ \\
\hline $\begin{array}{l}\text { Level } 3 \\
\text { Graetz Bridge }\end{array}$ & $\begin{array}{l}\text { Align diodes. Solve for } C \text { given } \\
V p p, R \text {, } f \text { to get target output } V\end{array}$ & $C=\frac{V p p}{2 \times R \times f \times V_{\text {smooth }}}$ & $\begin{array}{l}\text { Convert } \mathrm{AC} \text { to } \mathrm{DC} \text {. Ripple reduction } \\
\text { using capacitors. Diodes in rectification. }\end{array}$ \\
\hline $\begin{array}{c}\text { Level } 4 \\
\text { Wheatstone }\end{array}$ & $\begin{array}{l}\text { Solve for } \mathrm{Rx} \text { given } \mathrm{R} 1, \mathrm{R} 2, \mathrm{R} 3 \text { and } \\
\mathrm{Vpp} \text {. Balance bridge } \mathrm{Vg}=0\end{array}$ & $V_{g}=V_{p p} \times\left(\frac{R_{2}}{R_{1}+R_{2}}-\frac{R_{X}}{R_{3}+R_{X}}\right)$ & $\begin{array}{l}\text { Components/operation of bridge. Find } \\
\text { unknown resistance value using circuit. }\end{array}$ \\
\hline $\begin{array}{l}\text { Level } 5 \\
\text { Summing } \\
\text { amplifier }\end{array}$ & $\begin{array}{l}\text { Solve for } \mathrm{R} 0 \text { given } \mathrm{R} 1, \mathrm{R} 2, \mathrm{R} 3 \text { to } \\
\text { achieve target Vout }\end{array}$ & $V_{\text {out }}=-R_{0}\left(\frac{V e_{1}}{R_{1}}+\frac{V e_{2}}{R_{2}}+\frac{V e_{3}}{R_{3}}\right)$ & $\begin{array}{l}\text { Op amps in summing amplifiers } \\
\text { Relationship input/output Voltage } \\
\text { Role of feedback resistor (R0) }\end{array}$ \\
\hline $\begin{array}{l}\text { Level } 6 \\
\text { Transistor } \\
\text { switch }\end{array}$ & $\begin{array}{l}\text { Solve for } \mathrm{Rin} \text { and } \mathrm{Rl} \text { given } \mathrm{Vpp} \text {, } \\
\text { Vin to achieve target IC. }\end{array}$ & $I_{C}=\frac{V_{p p}-V_{C E s a t}}{R_{l}}$ & $\begin{array}{l}\text { Understand saturation/cut-off in } \\
\text { transistor as switches. } \\
\text { Relationship between RC and IC }\end{array}$ \\
\hline $\begin{array}{l}\text { Level } 7 \\
\text { Oscillator }\end{array}$ & $\begin{array}{l}\text { Solve for } \mathrm{R} 2, \mathrm{R} 3 \text { and } \mathrm{C} \text { to achieve } \\
\text { target frequency and Vpp }\end{array}$ & $f=\frac{1}{2 \times R_{3} \times C \times \ln \left(1+2 \frac{R_{1}}{R_{2}}\right)}$ & $\begin{array}{l}\text { Convert DC source to }(\mathrm{AC}) \text {. Compute } \\
\text { oscillation frequency from components. }\end{array}$ \\
\hline
\end{tabular}

Fig. 2. Player objective on each level, and the learning outcomes 
Circuit warz is a strategy game [25], where the player learns through the activities performed during the game phase, and $\mathrm{x}$ interactions with an environment in which he is confronted with various problems situation belonging to the same family. The game must offer the learners a situation that they can live a significant immersion, and in this situation the knowledge will appear as the optimal solution to the problems presented [26]. The game circuit Warz includes several problem situations necessary to the acquisition of the competences defined by the pedagogical objectives.

\section{$4 \quad$ Methodology}

\subsection{Research design}

So as to make the learner active in the process of learning, the teacher has to use different methods and various teaching procedures. The most used method by the vast majority of teachers is the statement of a problem situation, which gives the learner the opportunity to reflect and to activate his knowledge to solve the problem. In this study we compare two teaching sessions, one with a classic problem situation and another based on an educational game.

The game presented here was practiced during a two hour session; it was given in the second quarter of the school year in a grade 5 class. It is about the association of ohmic conductors and the voltage divider.

Due to the lack of computers, learners freely formed groups of 4 to 5 learners. Each learner was provided with a form to record the relevant information from the game phase. At the end of the experimental part, the learner will use this form to respond to questions from the teacher intended for the evaluation of knowledge, a questionnaire distributed after the end of the session to collect the appreciations of each one and the points of view on the various points of the experiment.

The study was organized in four classes from two different cities, Fez and Arfoud, two classes with an educational game and two classes with the traditional method, the study was as follows: 
Table 2. Conducting of the experiment

\begin{tabular}{|c|c|c|}
\hline Game group & Traditional group & Dedicated Time \\
\hline \multicolumn{2}{|c|}{$\begin{array}{l}\text { Introduction: Reminding the ohm's law and the association of ohmic conduc- } \\
\text { tors. }\end{array}$} & $30 \mathrm{~min}$ \\
\hline $\begin{array}{l}\text { Present a problem situation } \\
\text { included in the circuit warz } \\
\text { game and give instructions to } \\
\text { the students. }\end{array}$ & $\begin{array}{l}\text { State a problem situation that deals with the } \\
\text { concept of the voltage divider }\end{array}$ & $10 \mathrm{~min}$ \\
\hline \multirow{2}{*}{$\begin{array}{l}\text { Playing on the computer as a } \\
\text { group (group discussion) With } \\
\text { the filling of a form. }\end{array}$} & $\begin{array}{l}\text { Collect and discuss students' hypotheses } \\
\text { about the given situation. }\end{array}$ & $20 \mathrm{~min}$ \\
\hline & Check students' assumptions $20 \mathrm{~min}$ & $20 \mathrm{~min}$ \\
\hline $\begin{array}{l}\text { Responded to questions from } \\
\text { the teacher after playing and } \\
\text { subsequently deduce the voltage } \\
\text { divider formula. }\end{array}$ & Give students an exercise for practice. & $20 \mathrm{~min}$ \\
\hline $\begin{array}{l}\text { Play again the first part to recap } \\
\text { and improve the score taken. }\end{array}$ & Correction of the exercise. & $15 \mathrm{~min}$ \\
\hline \multicolumn{3}{|c|}{ End of the session } \\
\hline \multicolumn{3}{|c|}{$\begin{array}{l}\text { Gather the appreciations and opinions of learners concerning the evaluation of the session by } \\
\text { handing out a questionnaire for each group. }\end{array}$} \\
\hline \multicolumn{3}{|c|}{$\begin{array}{l}\text { Gather the appreciations and opinions of learners concerning the evaluation of the session by } \\
\text { handing out a questionnaire for each group. }\end{array}$} \\
\hline
\end{tabular}

\subsection{Participants / population of the study}

We took two classes from two different cities (Fez and Arfoud) with two different teachers; each class was randomly divided into two groups, one to apply the educational game and the other to use the classical method. In the beginning of the session, the teacher gave a justification for ten minutes using the projector to explain the instructions on how to use the game and in the game phase it gives the necessary guidance for each group.

The distribution of learners is as follows:

Table 3. The distribution of learners

\begin{tabular}{|l|c|c|c|}
\hline & Traditional group & Game group & Number of learners \\
\hline High school A (Fez) Teacher A & 20 students & 20 students & 40 students \\
\hline High school B (Arfoud) Teacher B & 18 students & 18 students & 36 students \\
\hline
\end{tabular}

\subsection{Questionnaire}

To carry out this research, we have developed two questionnaires, one for the educational game group and the other for the classical group; these two questionnaires are designed in such a way as to collect information about engagement, motivation and interactions between the learners and between the teacher and the learner as well. 


\section{$5 \quad$ Results}

\subsection{Comparison between the two groups with regard to motivation and en- gagement.}

Motivation: At the end of the session, we noted the opinions of the learners who answered the various questions we asked in the questionnaire

Table 4. .Learners 'replies to motivation questions

\begin{tabular}{|l|c|c|c|c|c|c|c|}
\hline \multicolumn{7}{|c|}{ Game Group } \\
\cline { 2 - 9 } & Group of Fez & \multicolumn{2}{|c|}{ Group of Arfoud } & Total of answers \\
\hline & Yes & No & Yes & No & Yes & No \\
\hline The appreciation of use educational game & 18 & 2 & 14 & 4 & 32 & 6 \\
\hline The game made the course more practical. & 18 & 2 & 15 & 3 & 33 & 5 \\
\hline $\begin{array}{l}\text { The course would have been treated better with } \\
\text { other digital media. }\end{array}$ & 3 & 17 & 3 & 15 & 6 & 32 \\
\hline $\begin{array}{l}\text { Would you like to use educational video games } \\
\text { more often in physics lessons? }\end{array}$ & 19 & 1 & 14 & 4 & 33 & 5 \\
\hline
\end{tabular}

Table 5. Learners 'replies to motivation questions and interest to use educational games

\begin{tabular}{|l|c|c|c|c|c|c|}
\hline \multicolumn{7}{|c|}{ Traditional Group } \\
\hline & Group of Fe & \multicolumn{1}{c|}{ Group of Arfoud } & Total of answers \\
\cline { 2 - 8 } & Yes & No & Yes & No & Yes & No \\
\hline Are you motivated during the session? & 7 & 13 & 5 & 13 & 12 & 26 \\
\hline $\begin{array}{l}\text { Do you think this course would have been } \\
\text { handled better with digital support? }\end{array}$ & 17 & 3 & 14 & 4 & 31 & 7 \\
\hline $\begin{array}{l}\text { Would you like to use educational video games } \\
\text { in the lessons of physics? }\end{array}$ & 18 & 2 & 15 & 3 & 33 & 5 \\
\hline
\end{tabular}

The examination of these two tables 4 and 5 shows that the students of the game group of Arfoud and Fez are motivated by the use of educational game in class. On the other hand, the students of traditional group are demotivated during the session.

The overall percentage results for both groups are the following:

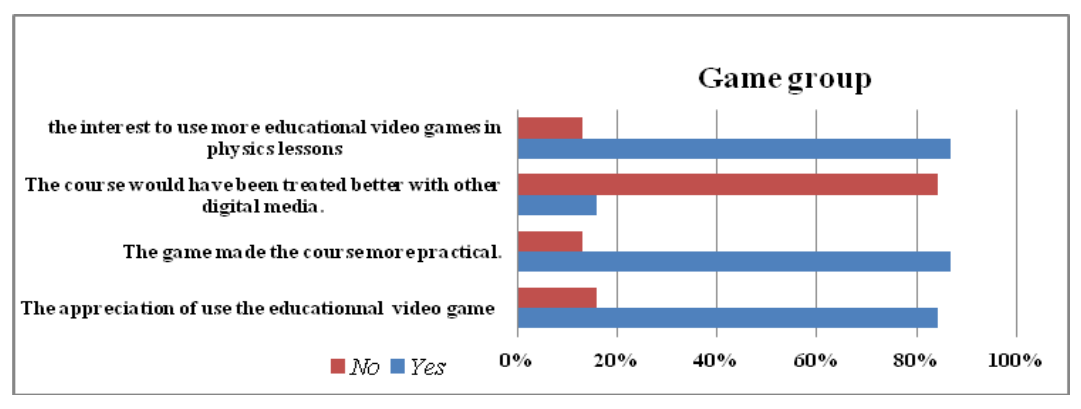

Fig. 3. An assessment of the motivation to use educational games 


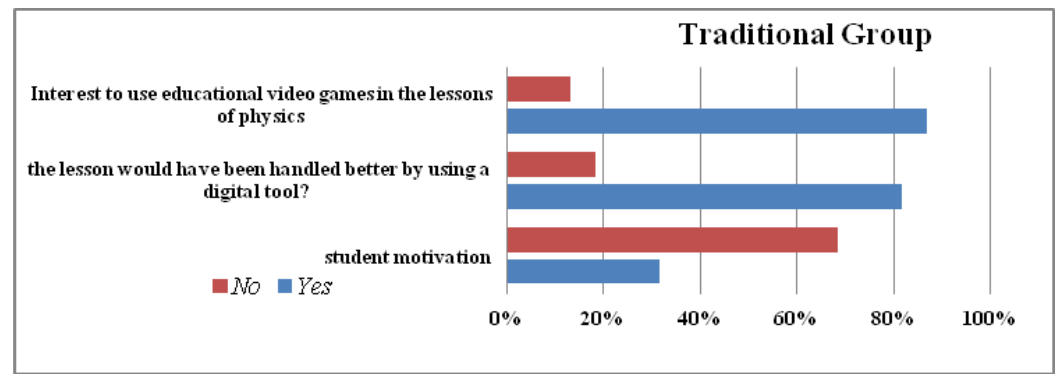

Fig. 4. An assessment of the motivation to learn with a traditional method and of interest to use educational games

In fact, this new way of learning is positively perceived by (84\%) learners who enjoy using the circuit warz game in class, in the eyes of many of them (87\%) teaching with using this tool has made the course more convenient and they wish to use it often $(87 \%)$ therefore they aren't interested (84\%) in learning with another digital medium. These results approve once again the motivation of learners to learn using educational games. The majority of the students liked their experiences using educational game circuit warz.

In addition, as reported the table 4, learners of Arfoud game group and learners of $f e z$ game group did not demonstrate differences in motivation, nor were interest. This suggests that educational games provide a relatively novel experience that does not favour students from one city to the other. In this sense, we can say that the use of educational games eliminates the spatial disparities between learners. Azriel say "regardless of age or economic, ethnic, or social background, people understand the language of play" [27].

In the same vein, the change of teacher did not influence on results of the two game groups. Indeed, the use of educational games has the possibility to allow students to learn in consistent conditions.

On the contrary, the result in the figure 4 of traditional group shows that $68 \%$ of learners are unmotivated during the session, and $82 \%$ of them want to use digital tool and especially educational games. This result is consistent with the classroom observations that many studies showed that the traditional method did not have a motivational effect on the students [28]. The use of educational games can be powerful resources for improving the teaching-learning process, since they are able to generate a motivation that the Moroccan learners needs.

Engagement: When we think of students 'engagement in learning activities, it is often convenient to understand engagement with an activity as being remarked by using two types of strategies: a learning strategy or a self-regulation strategy.

Learning Strategies: Are used by learners to "learn, integrate and remember" [29] concepts and notions in the classroom. For example, the strategies of memorization during the repetition of the contents in class and the strategies of elaboration which make it possible to make links between the notions seen.

Self-regulation strategies: "Are cognitive strategies that students use consciously, systematically and constantly when they take responsibility for their learning"[30], 
These self-regulation strategies have three strategies: metacognitive strategies that manifest themselves by planning a task, or self-assessment, management strategies such as work organization, choosing a place to study, and motivational strategies such as goal setting, rewarding end of work

The engagement of the learner is kept by the means of the motivation and the utilization of the resources to solve the problems situations, to use a lot of strategy before solving a problem situation allows the learner to develop methods of work, to follow logic; it also makes it possible to muster a large number of resources for the learner and subsequently to develop several skills, namely: calculation, decision-making, logical reasoning, they also promote his understanding of the lesson with his own method. In this context, we have raised two questions, which measure this, one question for each group.

Table 6. Learners 'replies to question "Have you tried a lot of strategies before tuning the generator? “

\begin{tabular}{|c|c|c|c|c|c|}
\hline \multicolumn{7}{|c|}{ Game group } \\
\hline \multicolumn{7}{|c|}{ Group of Fez } & & \multicolumn{3}{c|}{ Group of Arfoud } \\
\hline Yes & NO & Indifferent & Yes & NO & Indifferent \\
\hline 16 & 4 & 0 & 13 & 4 & 1 \\
\hline
\end{tabular}

Table 7. Learners 'replies to question "Have you tried a lot of methods before solving the proposed situation? “

\begin{tabular}{|c|c|c|c|c|c|}
\hline \multicolumn{7}{|c|}{ Traditional Group } \\
\hline \multicolumn{7}{|c|}{ Group of Fez } & & \multicolumn{3}{c|}{ Group of Arfoud } \\
\hline Yes & No & Indifferent & Yes & No & Indifferent \\
\hline 7 & 11 & 2 & 5 & 12 & 1 \\
\hline
\end{tabular}

The two histograms below re-group the result of the two groups in percentage.

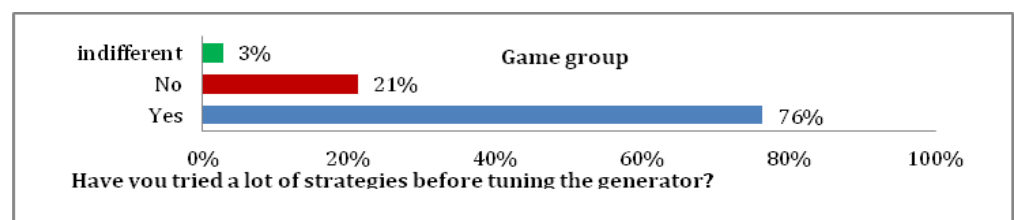

Fig. 5. Engagement of students in the learning process (game group)

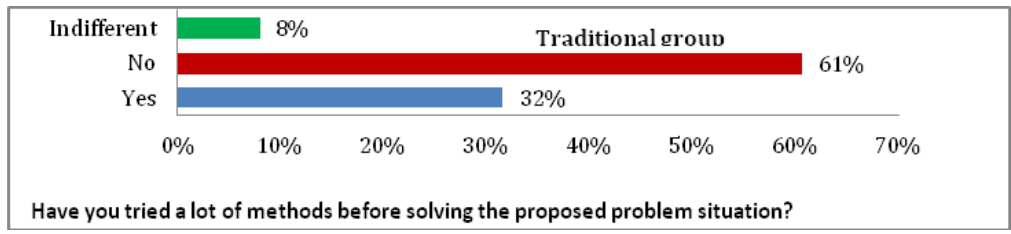

Fig. 6. Engagement of students in the learning process (traditional group) 
As depicted in figure 5, the result clearly shows that engagement and resource utilization were too high for more than $70 \%$ of learners. In other words, learners move from being passive recipients of knowledge to being participants in activities, in fact, the use of educational games improve student's engagement in the process of thinking, questioning, and problem solving.

Reading the histogram of the figure 6 , shows that there are almost $60 \%$ learners did not use a lot of methods before solving the proposed problem situation. The engagement was low compared to the session of the educational game.

In sum, the course with the game is more motivating and engaging than the traditional course. If the competency-based approach wanted to be successful, they should be supported by using educational games.

In this teaching process, the purpose of an educational game is twofold: to create a fun environment, and to be educational.

An educational game is thus designed both to be attractive and appealing to a broad target audience, similar to commercial games, and to meet specific educational goals as well. In this regard we asked a question to gather opinions on this point.

During the use of this educational video game, did you get the impression?

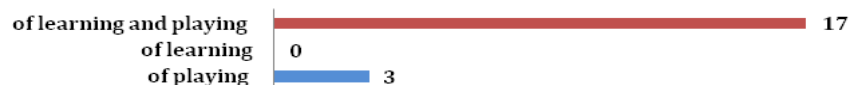

Fig. 7. Learners 'replies to question "During the use of this educational video game, did you get the impression? (Fez group)

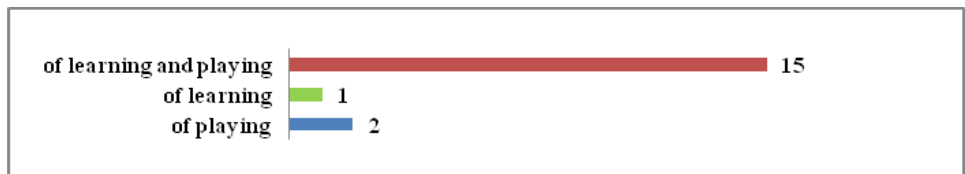

Fig. 8. Learners 'replies to question "During the use of this educational video game, did you get the impression? (Arfoud group)

The purpose of this question was to determine learners' perceptions about the use of educational games. According to the result of this question; learners consider educational games as a fun and learning-aids tool, these two dimensions allow the learners to be engaged in learning situations thus these tools deserve an important place in the field of teaching.

\subsection{Comparison between the two groups with respect to interaction.}

As part of the competency based-approach we commonly tend to have interactions inter-learners in the classroom. In fact, this type of interaction promotes peer learning and develops communication skills, argumentation in the learner. The results we have obtained at this level are encouraging, they are as follows: 
Table 8. Learners' responses about classroom interaction.

\begin{tabular}{|c|c|c|c|c|c|c|c|c|c|c|c|c|}
\hline & \multicolumn{6}{|c|}{ Game group } & \multicolumn{6}{|c|}{ Traditional group } \\
\hline & \multicolumn{3}{|c|}{ Group of Fez } & \multicolumn{3}{|c|}{ Group of Arfoud } & \multicolumn{3}{|c|}{ Group of Fez } & \multicolumn{3}{|c|}{ Group of Arfoud } \\
\hline & Yes & No & Indifferent & Yes & No & Indifferent & Yes & No & Indifferent & Yes & No & Indifferent \\
\hline $\begin{array}{l}\text { Interactions } \\
\text { with your } \\
\text { teacher were } \\
\text { minimal. }\end{array}$ & 9 & 8 & 3 & 10 & 7 & 1 & 3 & 17 & 0 & 5 & 11 & 2 \\
\hline \begin{tabular}{|l|} 
Interactions \\
with your \\
colleagues were \\
numerous.
\end{tabular} & 18 & 2 & 0 & 15 & 3 & 0 & 3 & 15 & 2 & 6 & 11 & 1 \\
\hline
\end{tabular}

Concerning the two game groups, the results were not significantly different, they converge towards the same conclusion, the learners interact a lot with each other, and the learning is no longer centred on the teacher as interactions with him were minimal.

The results for both groups, expressed as a percentage, are as follows.

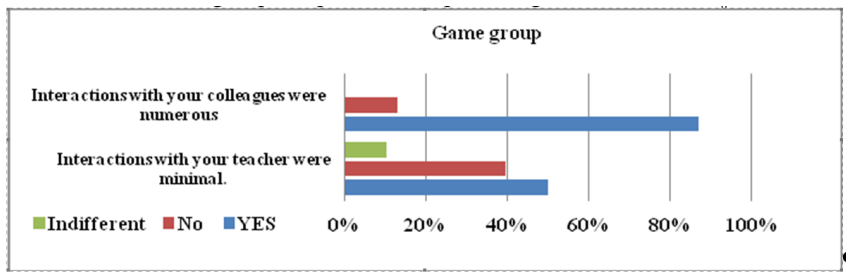

Fig. 9. An assessment of the interaction inter-learners and teacher-learner (Game group)

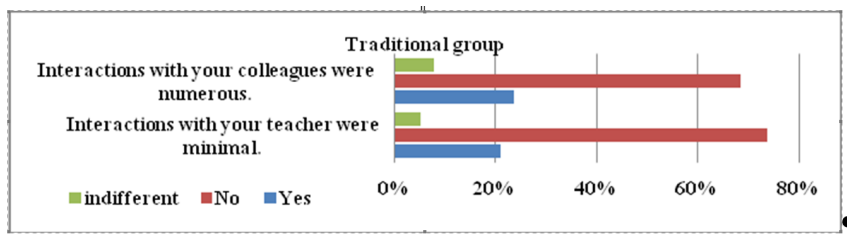

Fig. 10.An assessment of the interaction inter-learners and teacher-learner (Traditional group)

As illustrated in Figure 9, the results show that half of the learners do not interact with their teacher but the interactions between them are too high $(87 \%)$. Interactions inter-learners in the classroom are achievable through the integration of an educational game. Furthermore, the use of these pedagogical tools can contribute on integrating students and promoting a creative and social learning environment. We can say that the effective use of educational games enhances the interactive process between students.

We can also note that peer Interaction operates in a different mode. Most common perhaps is oral interaction, but in all cases, learners need a reason to interact with each other, in this sense, the use of educational games in classroom can be a good reason. 
In the same frame, as shown on figure 10, the majority of interactions occur between the learner and the teacher $(74 \%)$, in the other side, learners interact weakly with each other (24\%). We can say that students are so closely attached to the teacher.

The absence of interaction inter-learners that results in a teacher-centred learning will not facilitate implementation of the competency-based approach.

The comparison of the interactions between game group and traditional group makes us understand that if we want more interaction inter-learners and make the learner a participant in their learning, we must ensure that educational games are integrated into the curriculum of physics classes.

\section{Conclusion}

The results of this study showed that the use of circuit warz in class allows a renewal of motivation and engagement. The learners in the application group were more motivated and engaged in the learning act than the learners in the traditional group. This pedagogical tool is in line with the philosophy of the competency-based approach: playing an educational video game as a circuit warz makes it possible to set up an environment based on the construction of knowledge.

On the other hand, the integration of circuit warz in the classroom has fostered peer interaction, as the results indicate, which encourages peer learning. We also found that these results were similar for both educational game groups whether for Fez or Arfoud. This proves that the integration of the game is not influenced too much by the teacher's change or by the learners' social environment.

To continue research on the contribution of educational games to physics education, similar studies should be conducted for other games to see the interest of everyone. We must also work on pedagogical scenarios in order to find the best way to use this pedagogical tool. This sum of studies will constitute a set of data for researchers and teachers.

\section{$7 \quad$ References}

[1] Brom, C., Preuss, M., \& Klement, D. (2011). Are educational computer micro-games engaging and effective for knowledge acquisition at high-schools? A quasi experimental study. Computers \& Education, 57 (2011), https://doi.org/10.1016/i.compedu.2011.04.007

[2] van der Graaf, Joep \& Segers, Eliane \& Verhoeven, Ludo. (2016). Discovering the laws of physics with a serious game in kindergarten. Computers \& Education. https://doi.org/10. 1016/j.compedu.2016.06.006

[3] Khenissi, M. A., Essalmi, F., and Jemni, M., 2014. Comparison between serious games and learning version of existing games. In Proceedings of the 6th World Conference on Educational Sciences. https://doi.org/10.1016/j.sbspro.2015.04.380

[4] G. Hookway et al., "Learning physics through computer games," The 18th International Conference on Computer Games, 2013. https://doi.org/10.1109/CGames.2013.6632617

[5] Khouna, Jalal \& Ajana, Lotfi \& Rhazal, Ahmed \& El Hajjami, Abdelkrim. (2017). Introducing Educational Games in the Teaching of Physics in Moroccan Secondary Schools. IOSR Journal of Research \& Method in Education (IOSRJRME). 07. 19-28. https://doi.org/10. $\underline{\text { 9790/7388-0704011928 }}$ 
[6] Sauvé Louise, Renaud Lise \& Gauvin Mathieu (2007). « Une analyse des écrits sur les impacts du jeu sur l'apprentissage ». Revue des sciences de l'éducation. https://doi.org/10.72 02/016190ar

[7] Hursen, Cigdem, \& Cizem Bas. "Use of Gamification Applications in Science Education." International Journal of Emerging Technologies in Learning (iJET) [Online], 14.01 (2019): pp. 4-23. Web. 9 Apr. 2019 https://doi.org/10.3991/ijet.v14i01.8894

[8] Williamson, B. 2009. Computer Games, Schools and Young People: A Report for Educators on Using Games for Learning. Rapport de recherche. Bristol: Future lab.

[9] Westera, Wim. (2015). Games are motivating, aren't they? Disputing the arguments for digital game-based learning. International Journal of Serious Games. 8. https://doi.org/10. 17083/ijsg.v2i2.58

[10] Kahn, S. et Rey, B. (2016). La notion de competence: une approche épistémologique. Éducation et francophonie, 44(2), 4-18. https://doi.org/10.7202/1039019ar

[11] Audet, Lucie. 2009. « Mémoire sur le development de compétences pour l'apprentissage à distance: Points de vue des enseignants, tuteurs et apprenants ». Réseau d'enseignement francophone à distance du Canada.

[12] Forget, Pascal. 2015. « Les jeux sérieux au service de l'apprentissage ». In Le Tableau, vol.4, no 5. Gagnon-Mountzouris, Vicky. 2012. La techno-pédagogie au service de la formation: l'apprentissage par les jeux dans les bibliothèques.

[13] Rivard, Patrick. 2015. « Ludification: apprendre par plaisir et bien plus! »

[14] Sanchez, Eric, Muriel Ney et Jean-Marc Labat. 2011. « Jeux sérieux et pédagogie universitaire: de la conception à l'évaluation des apprentissages ». Revue internationale des technologies en pédagogie universitaire, vol 8, no 1-2, p. 48-57. https://doi.org/10.7202/1005783ar

[15] Hamari, J., Shernoff, D.J., Rowe, E., Coller, B., Asbell-Clarke, J. et Edwards, T. (2016). Challenging games help students learn: An empirical study on engagement, flow and immersion in game-based learning. Computers in Human Behavior, 54, 170-179. https://doi.org/10.1016/j.chb.2015.07.045

[16] Kirriemuir, J. et McFarlane, A. (2004). Literature Review in Games and Learning. Rapport A NESTA Futurelab Research report - report 8. Bristol: Futurelab.

[17] Prensky, M. (2001). Digital game-based learning. New York: McGraw-Hill.

[18] Oblinger, D.G., 2004. The Next Generation of Educational Engagement. Journal of Interactive Media in Education, 2004(1), p.Art. 10. https://doi.org/10.5334/2004-8-oblinger

[19] Sonia Trajcev. Grille d'analyse d'un jeu éducatif 2017 http://creaje.fr/wpcontent/uploads/2017/05/Grille-analyse-jeu-éducatif_Sonia-Trajcev2017.pdf

[20] Fishman, B., Riconscente, M., Snider, R., Tsai, T., et Plass, J. (2015). Empowering Educators: Supporting Student Progress in the Classroom with Digital Games (Part 2). Ann Arbor: University of Michigan.

[21] Olivier Mathieu 2018: conception d'une grille d'analyse des jeux sérieux pour l'enseignement de la science et de la technologie au secondaire en regard des bonnes pratiques reconnues dans le domaine de l'apprentissage par le jeu video 2018- faculté d'éducation university de sherbrooke.

[22] ITECO Centre de formation pour le development, Grille d'analyse d'outils pédagogiques créés en Education au Development (ED) et à la Citoyenneté Mondiale (ECM). ITECO 2012

[23] El Borji, Yassine. (2014). Comparative Study to Develop a Tool for the Quality Assessment of Serious Games Intended to be Used in Education. International Journal of Emerging Technologies in Learning (iJET). 9. https://doi.org/10.3991/ijet.v9i9.4150

[24] Equipe TICE économie-gestion de l'académie de Toulouse Académie deToulouse: une grille d'analyse pour les jeux sérieux en économie gestion 2012 https://disciplines.ac-montpellier.fr/economie-gestion/sites/economie getion/files/jeux serieux/jeux serieux simuland/grille analyse simuland v5 0.pdf

[25] MJ. Callaghan, M. Savin-Baden, N. McShane and A. Gómez Eguíluz: Mapping Learning and Game Mechanics for Serious Games Analysis in Engineering Education. School of Computing and Intelligent Systems Ulster University, Derry, Northern Ireland, UK

[26] Brousseau G., Théorie des situations didactiques, Grenoble, La Pensée Sauvage, 1998. 
[27] Azriel, J., Erthal, M., Starr, E., Answers, Questions, and Deceptions: What Is the Role of Games in Business Education. Journal of Education for Business, Sept/Oct 2005, p.9-13. https://doi.org/10.3200/JOEB.81.1.9-14

[28] Zheng, Yue. (2019). 3D Course Teaching Based on Educational Game Development Theory â€"Case Study of Game Design Course. International Journal of Emerging Technologies in Learning (iJET). 14. 54. https://doi.org/10.3991/ijet.v14i02.9985

[29] Darveau, P. \& Viau, R. (1997). La motivation des enfants. Le rôle des parents. Québec: Les Éditions du Renouveau Pédagogique Inc. p.78).

[30] Darveau, P. \& Viau, R. (1997). La motivation des enfants. Le rôle des parents. Québec: Les Éditions du Renouveau Pédagogique Inc. p.83).

\section{Authors}

Jalal Khouna is a $\mathrm{PhD}$ student at the Interdisciplinary Laboratory of Research in Didactics of Sciences and Technology (ILRDIST), Faculty of Sciences Dhar El Mahraz, Sidi Mohammed Ben Abdellah University, B.P. 1796, Fez-Atlas 30003, Morocco. His research focused on educational games, competency-based approach and integration of ICT into teaching and learning.

Lotfi Ajana is a professor at ENS (école normale supérieure), sidi Mohamed Ben Abdellah university, Fez Morocco. Founding member and permanent member of laboratory Interdisciplinary of research in didactics science and technology (ILRDIST) and Team of research TICFS (Technologies of Information and Communication for Science Education). He does research in didactic science and TICE (Technologies of Information and Communication for Education).

Ahmed Rhazal is a PhD student at the Interdisciplinary Laboratory of Research in Didactics of Sciences and Technology (ILRDIST), Faculty of Sciences Dhar El Mahraz, Sidi Mohammed Ben Abdellah University, Fez, Morocco. His research focuses on ICT, e-learning and school support.

Abdelilah El Mokri is a professor at ENS (école normale supérieure) sidi Mohamed Ben Abdellah university, Fez Morrocco, member of laboratory of Computer and Interdisciplinary Physics (LIPI). He does research in TICE.

Article submitted 2019-04-09. Resubmitted 2019-06-12. Final acceptance 2019-06-15. Final version published as submitted by the authors. 